\title{
Manajemen Pendidikan dan Pelatihan Santri Siap Guna dalam Membentuk Karakter Santri "Baku"
}

\author{
Kikin Sakinah*, Fisher Zulkarnaen, \& Dewi Sadiah \\ Jurusan Manajemen Dakwah, UIN Sunan Gunung Djati, Bandung \\ "Email: kikinsakinab@studentuinsgd.ac.id
}

\begin{abstract}
ABSTRAK
Penelitian ini bertujuan untuk mengetahui manajemen pendidikan dan pelatihan Santri Siap Guna (SSG) dalam membentuk karakter santri Baku (Baik dan Kuat). Metode penelitian yang digunakan adalah metode deskriptif dengan pendekatan kualitatif, bertujuan untuk menggambarkan, memaparkan, dan menjelaskan datadata mengenai manajemen pendidikan dan pelatihan SSG dalam membentuk karakter santri Baku, yaitu melalui wawancara, observasi, studi dokumentasi kepada objek penelitian tersebut. Dari hasil penelitian ini dapat diketahui bahwa manajemen diklat yang dilakukan SSG dalam membentuk karakter santri Baku telah memenuhi kebutuhan diklat. Hal ini terlihat dari pengelolaan perencanaan, pelaksanaan, dan evaluasi yang sejalan dengan panduan diklat pada umumnya. Selain itu keberhasilan dalam membentuk karakter Baku terlihat dari perubahan peserta usai mengikuti diklat serta adanya program berkelanjutan. Berdasarkan penelitian ini dapat disimpulkan bahwa manajemen pendidikan dan pelatihan SSG dalam membentuk karakter santri Baku telah berhasil dan peserta mampu menerapkan nilai-nilai yang berkarakter Baku.
\end{abstract}

Kata Kunci: Manajemen; Diklat; Santri Siap Guna; Karakter.

\section{ABSTRACT}

This study aims to find out the management of education and training of Santri Siap Guna (SSG) in shaping the character of santri Baku (Baik and Kuat). The research method used is descriptive method with qualitative approach, aims to describe, describe, and explain data about management education and training SSG in shaping character of santri Baku, that is through interview, observation, documentation study to object of the research. From the results of this study it can be seen that the training of training done by SSG in shaping the character of santri Baku has fulfilled the training requirement. This is evident from the management of planning, implementation and evaluation in line with the training manual in general. In addition, the success in shaping the character of Baku is seen from the change of participants after attending the training and the continuity of the program. Based on this research, it can be concluded that SSG education and training management in shaping the character of santri Baku has been successful and the participants are able to apply the values of Baku character.

Keywords: Training; Management; Santri Siap Guna; Characters 


\section{PENDAHULUAN}

Dalam kehidupan sehari-hari manusia tidak terhindar dari aturan-aturan. Islam tidak membatasi muslim untuk bertindak, meskipun pada dasarnya Islam sendiri memiliki aturan. Akan tetapi hal tersebut masih dalam tahap penawaran, yang artinya muslim diberitahukan secara penuh hak untuk memilih aturan mana yang akan diambilnya. Aturan terkait dengan kemampuan seseorang dalam organisasi. Jika dapat menjalankan fungsinya dengan baik, maka organisasi tersebut dapat melaksanakan pekerjaan secara efektif dan efisien.

Untuk mewujudkan hal tersebut maka manusia perlu memliki kompetensi yang sesuai dengan bidang pekerjaannya. Apabila kompetensinya tidak sesuai atau kurang memenuhi ketentuan pekerjaan, hal ini perlu dilatih (training) agar dapat melaksanakan tugas pokoknya secara efektif dan efisien.

Pendidikan dan Pelatihan (Diklat) merupakan suatu proses pembelajaran dalam organisasi yang mengarah pada perubahan sikap dan perilaku pegawai memenuhi harapan kualitas kerja dan tuntutan perkembangan organisasi baik intenal maupun eksternal. Dalam hal ini proses perubahan yang dilakukan adalah terhadap santri.

Santri adalah seseorang yang mengemban pendidikan dilingkungan pesantren. Mengenal santri bukan hanya melulu soal kitab dan sarung lebih dari itu santri sebagai sumber daya manusia merupakan aset bangsa. Santri berperan penting dalam kemajuan bangsa Indonesia. Saat ini eksistensi santri masih tetap ada, di dalam lingkungan yang disebut pesantren. Santri sebagai pemuda, berbeda dengan pemuda pada umumnya. Santri memiliki kelebihan khususnya dalam pemahaman agama. Kelebihan dalam pemahaman agama yang dimiliki oleh santri tentu saja tidak akan seimbang jika tidak dilandaskan pada karakter atau akhlak santri.

Dewasa ini generasi muda mengalami krisis moral. Kesantunan dan akhlak yang baik mulai luntur. Kejadian krisis moral seperti tawuran, pergaulan bebas dan tidak taat aturan, semakin terlihat jelas. Saat ini generasi muda telah banyak terpengaruh oleh kehidupan yang bebas. Tidak taat aturan dan berlaku kurang baik. Contoh kecil pada lingkungan kampus: membuang sampah sembarangan, parkir kendaraan yang tidak sesuai, hingga berpakaian yang kurang mencerminkan kepribadian muslim. Keadaan seperti ini yang perlu diperhatikan tentunya untuk memperbaiki karakter.

Sebagai pemuda aset bangsa santri harus bisa menjadi pelopor dalam memperbaiki keadaan ini serta mampu memperkuat pertahanan diri. Santri bukan hanya bergelut dalam lingkungan yang disebut pesantren, kini santri pun harus mampu melihat dan berada dalam cakrawala yang lebih luas setelah mendapat pendidikan di pesantren. Karakter atau akhlak santri yang tangguh sangat dibutuhkan untuk negeri ini bahkan sudah saatnya perlu di implementasikan dalam diri santri. Santri yang mempunyai akhlak mulia serta kuat pada ketahanan fisik nya menjadi bagian dalam pembentukan karakter seorang santri.

Dalam upaya pembentukan karakter atau akhlak santri ada beberapa faktor 
yang dapat mempengaruhinya, diantara faktor tersebut yaitu keluarga. Keluarga menjadi bagian terpenting dalam membentuk santri sebagai generasi muslim yang berakhlak mulia. Orangtua adalah madrasah pertama bagi anak. Selain peran orang tua, sekolah juga sebagai sarana untuk mendidik santri agar mempunyai karakter. Sekolah merupakan wadah yang sangat efektif untuk membentuk siswa yang berbudi pekerti dan berkarakter tinggi.

Faktor yang tidak kalah penting yaitu adalah lingkungan. Seseorang dapat baik jika di dalam lingkungannya dia bergaul dengan orang-orang yang baik. Satu orang yang mempunyai akhlak baik berada di dalam seratus orang yang tidak baik dia akan menjadi tidak baik dan sebaliknya, jika ada satu orang yang bermoral buruk berada di antara orang-orang yang baik dia akan menjadi baik. Dalam upaya ini keluarga harus mampu mencari lembaga pendidikan yang kiranya dapat menunjang anak untuk bisa mendapat ilmu umum sekaligus mengasah agamanya.

Pembentukan karakter dan watak yang baik sangat penting bagi santri agar terlahirnya generasi baru yang kuat dan berguna bagi bangsa. Di dalam tubuh yang kuat terdapat jiwa yang sehat. Ungkapan ini sangat benar dan membangun untuk menjadikan pribadi yang kuat baik jasmani maupun rohani. Kecerdasan akal pikiran saja tidak cukup untuk membentuk kepribadian yang baik, tetapi juga kesehatan jiwa yang serta merta membangun pola pemikiran dalam kesuksesan pembelajaran. Pendidikan jasmani tidak hanya sekedar untuk kebugaran tubuh saja, tetapi juga melatih jiwa untuk berpikir sehat dan kritis yang diperlukan guna melahirkan individu santri Indonesia yang berkarakter.

Banyak cara untuk dapat membentuk karakter yang tangguh. Salah satunya dengan melakukan pendidikan non formal yaitu dengan mengikuti pendidikan dan pelatihan yang intensif. Pendidikan dan pelatihan (Diklat). Untuk pembentukan karakter memang tidak mudah. Diklat juga memerlukan waktu yang panjang. tetapi pembentukan karakter merupakan bagian terpenting dari pengembangan santri sebagai pemuda dan sumber daya manusia khususnya di Indonesia. Saat ini telah banyak lembaga Islam yang mampu membimbing santri dalam rangka pembentukkan karakter. Salah satu diantaranya adalah program diklat SSG yang diselenggarakan oleh Pondok Pesantren Daarut Tauhiid.

Pelatihan dan pendidikan (Diklat) Santri Siap Guna dirancang bagi santri non-mukim. Dalam kegiatannya SSG memfokuskan pada upaya peningkatan kualitas pembentukan karakter (fisik, mental, spiritual) dengan ikut serta diklat tersebut, seseorang akan mampu mengendalikan emosionalnya serta memiliki fisik dan mental yang kuat. Karakter tersebut merupakan karakter wajib yang dimiliki oleh seseorang khususnya generasi muda sebagai penerus pemimpin bangsa.

SSG Daarut Tauhiid berdiri dengan pendekatan visi membangun Indonesia bertauhid sebagai pelayanan masyarakat baik dibidang dakwah, ekonomi maupun sosial kemasyarakatan. Pendidikan dan pelatihan yang diterapkan lembaga Daarut Tauhiid harus memiliki karakter Baku singkatan dari Baik dan Kuat, Karakter Baik dengan Indikator: Jujur, Ikhlas, dan Tawadhu dalam setiap aktivitas dan karakter Kuat dengan indikator: Tangguh, Disiplin, dan Berani dalam melakukan 
kebaikan. Output program SSG tersebut berharap terjadi perubahan di masyarakat, sehingga terlahir santri yang ideal dan menyiapkan generasi muda yang punya kepribadian dan konsep hidup yang jelas.

Tentunya program Diklat yang dirancang hanya dengan waktu 3 bulan ini dengan waktu hanya 2 hari setiap pekannya memerlukan manajemen atau pengelolaaan yang terpadu agar pencapaian-pencapaian yang direncanakan dapat terwujud. Karena Diklat 3 bulan ini mampu menjadikan santri mengalami perubahan yang sangat luar biasa. Semua itu perlu pengelolaan atau manajemen yang baik.

Penelitian ini dilakukan pada Santri Siap Guna Daarut Tauhiid Angkatan 32 Jl. Geger Kalong Girang No. 67 Bandung. Alasannya masalah ini sangat penting untuk diteliti karena berkaitan dengan manajemen pendidikan dan pelatihan SSG Daarut Tauhiid dalam membentuk karakter santri Baku Lokasi ini relatif mudah terjangkau dari tempat tinggal peneliti, yang memungkinkan efektivitas dan efisiensi dalam pengumpulan data-data dan informasi yang dibutuhkan.

Untuk pertanyaan penelitian yang diajukan terhadap masalah yang diangkat yaitu berhubungan dengan manajemen pendidikan dan pelatihan SSG Daarut Tauhiid dalam membentuk karakter santri Baku, diantaranya: perencanaan, pelaksanaan dan evaluasi.

\section{LANDASAN TEORITIS}

Manajemen adalah ilmu dan seni yang mengatur proses pemanfaatan sumber daya lainnya secara efektif dan efisen untuk mencapai suatu tujuan tertentu. Dalam sumber lain disebutkan bahwa manajemen adalah proses, perencanaan, pengorganisasian, pengarahan, dan pengawasan berbagai usaha anggota organisasi dan penggunaan sumber daya organisasi untuk mencapai tujuan organisasi yang telah ditetapkan (Hasibuan, 2003:9)

Berdasarkan Inpres Nomor 15 tahun 1974 tentang Pelaksanaan Keppres Nomor 34 tahun 1972: pelatihan adalah bagian dari pendidikan yang menyangkut proses belajar untuk memperoleh dan meningkatkan keterampilan diluar sisitem pendidikan yang berlaku, dalam waktu yang relatif singkat dan metodenya mengutamakan praktek daripada teori.

Menurut Daryanto dan Bintoro (2014:26) Pendidikan dan pelatihan (Diklat) adalah rancangan suatu sistem dalam proses pengubahan sikap dan tata laku seseorang maupun peningkatan atau perolehan kemahiran (keterampilan) dalam rangka pendewasaan melalui upaya pengajaranan pelatihan. Dengan demikian pendidikan dan pelatihan merupakan cerminan dari pengalamanpengalaman belajar apa saja yang harus ditimba oleh peserta berdasarkan tujuan yang akan dicapai. Pengalaman belajar tersebut terdiri dari aspek pengetahuan, aspek keterampilan, aspek sikap terintegrasi dalam suatu proses pembelajaran hal tersebut harus tertuang dalam mata tataran atau materi diklat

Davies menjelaskan bahwa manajemen atau pengelolaan pelatihan merupakan proses penggunaan sumberdaya secara efektif untuk mencapai sasaran 
yang berupa kegiatan memahirkan. Sebagai suatu proses, manajemen pelatihan berdampingan dengan tiga aktivitas, yakni (a) perencanaan, (b) pelaksanaan, dan (c) evaluasi. Ketiga komponen tersebut dapat dijabarkan ke dalam sepuluh langkah kegiatan, yang disebut "pendekatan pelatihan sistematis". Pada umumnya daur manajemen pelatihan mengacu ke analisis, mendesain, mengembangkan, mengimplementasikan, dan mengevaluasi. Keberhasilan pelatihan ditentukan oleh berbagai komponen, antara lain, pelatih, bahan, media, strategi, dan kondisi pelatihan. Pelatih termasuk penentu utama keberhasilan.

Hal-hal yang perlu diperhatikan dalam merencanakan program pelatihan, antara lain: Latar belakang kegiatan (analisis kebutuhan), Tujuan pelatihan, Peserta pelatihan, Biaya/sumber dana, Waktu dan tempat pelatihan, Jadwal pelatihan (waktu, materi, dan pemateri), Susunan panitia pelaksana, Tata tertib; dan Narasumber.

Menurut Aep Kusnawan (2009:118) setelah kegiatan perencanaan sudah tersusun, berikutnya mulai memasuki tahap pelaksanaan. Adapun tahapan pelaksanaan pelatihan Diklat diawali dengan pembukaan, proses belajar dan penutupan.

Berdasarkan tingkatannya, evaluasi pelatihan dibagi menjadi 4 (empat) tahap (Kirk Patrick), yaitu : Evaluasi pada tingkat reaksi, pada tingkat ini, yang dinilai/diukur adalah tingkat kepuasan peserta terhadap proses dan hasil pelatihan yang diperolehnya. Evaluasi pada tingkat belajar. Pada tingkat ini, diukur/dinilai perubahan pengetahuan, keterampilan dan sikap peserta latih sesuai dengan kompetensi yang telah ditetapkan. Evaluasi pada tingkat tingkah laku dalam pekerjaan (pasca pelatihan). Pada tingkat ini, dinilai/diukur seberapa besar pengaruh pelatihan terhadap pekerjaan atau penerapan ditempat kerja.Evaluasi pada tingkat hasil, pada tingkat ini dapat dinilai pengaruh penerpan hasil pelatihan di tempat kerja terhadap efektifitas organisasi.

Prosedur pengelolaan pelatihan secara hierarkis yaitu: identifikasi dan analisis kebutuhan pelatihan, menguji dan analisis jabatan dan tugas,klasifikasi dan menentukan dan peserta pelatihan, rumuskan tujuan pelatihan, pendesainan kurikulum dan silabus pelatihan, perencanaan program pelatihan, penyusunan dan pengembangan kerangka acuan (tor), pelaksanaan program pelatihan., evaluasi program pelatihan, tindak lanjut pelatihan.

Adapun metode diklat dilihat dari tempat penyelenggaraannya dikelompokkan cara kedalam 3 (tiga) metode on-the-job adalah diklat yang diselenggarakan di tempat kerja pada saat karyawan bekerja dalam bentuk rotasi pekerjaan magang, atau coaching atau of the-job atau off-site training, adalah diklat yang diselenggarakan di luar tempat bekerja, dapat juga di lembaga diklat, dalam bentuk seminar atau kursus. dan development program adalah program peningkatan kompetensi konseptual manajer dengan mengikuti perkuliahan di perguruan tinggi atau kursus manajerial.

Menurut Abdorrakhman Gintings (2011: 43) ada 8 (delapan) komponen program diklat dalam mengembangkan sebuah program diklat. kedelapan 
komponen tersebut harus dirumuskan dan disiapkan secara cermat agar diklat secara produktif mencapai tujuan pengembangan SDM. Berbagai hal tentang komponen-komponen dimaksud, sebagai berikut: kebutuhan diklat, tujuan diklat, strategi penyelenggaraan, peserta diklat, pengajar, tempat diklat, peralatan, dan biaya diklat.

Karakter sebagaimana didefinisikan oleh Ryan dan Bohlin mengandung tiga unsur pokok, yaitu mengetahui kebaikan (knowing the good), mencintai kebaikan (loving the good), dan melakukan kebaikan (doing the good). Dalam pendidikan karakter, kebaikan itu sering kali dirangkum dalam sederet sifat-sifat baik.

Menurut Homby \& Parnwell karakter adalah kualitas atau moral, kekuatan moral, nama atau reputasi. Hermawan Kertajaya karakter adalah "ciri khas" yang dimiliki oleh suatu benda atau individu ciri tersebut adalah "asli" mengakar pada kepribadian benda atau individu tersebut dan merupakan 'mesin' pendorong bagaimana seorang bertindak, bersikap, berujar, dan merespons sesuatu.

Kata "santri" menurut Nurcholish Madjid dapat dilihat dari "santri" yang berasal dari perkataan "sastri", bahasa Sanskerta yang artinya melek huruf. Dan dii sisi lain, Zamkhsyari Dhofier mengatakan bahwa kata "santri" dapat diartikan buku-buku suci, buku-buku agama, atau buku-buku tentang ilmu pengetahuan.

Dari Kamus Umum Bahasa Indonesia (1990:997) kata santri mengandung beberapa pengertiani (1) orang yg mendalami agama Islam; (2) orang yang beribadat dengan sungguh-sungguh (orang yang saleh); (3) Orang yang mendalami pengajiannya dalam agama Islam dengan berguru ketempat yang jauh seperti pesantren dan lain sebagainya. Sehingga menurut para ahli, pengertian "santri" adalah panggilan untuk seseorang yang sedang menimba ilmu pendidikan agama Islam selama kurun waktu tertentu dengan jalan menetap di sebuah pondok pesantren. Santri merupakan peserta didik atau objek pendidikan, tetapi di beberapa pesantren, santri memiliki kelebihan potensial intelektual (santri senior) sekaligus mengajar santri-santri junior.

Menurut Erie (2011: 14) Karakter dapat dibedakan atas dua kategori, yakni Karakter Pokok dan Karakter Pilihan. Sebagai landasan seyogyanya karakter pokok harus dimiliki tiap orang. Apapun profesinya, semua harus berkarakter. Khususnya karakter pokok tidak bisa ditinggalkan. Karakter pilihan merupakan perilaku baik yang berkembang sesuai dengan profesi pekerjaan. Tiap profesi memiliki perilaku karakternya. Setiap orang harus membangun Karakter Pokok terlebih dahulu. Lebih khusus lagi, mereka wajib memiliki Karakter Dasar.

Karakteristik tidak terbentuk begitu saja, tetapi terbentuk melalui beberapa faktor yang mempengaruhi, yaitu: faktor biologis dan faktor lingkungan.

Menurut Muwafik Saleh (2012:12) ada 7 (tujuh) Metode dalam membangun karakter, yaitu sebagai berikut: melalui keteladanan, melalui simulasi praktik (experiental learning), metode ikom dan afirmasi (menempel dan menggantung), metode repeat power, metode 99 sifat utama, membangun kesepakatan nilai keunggulan, melalui penggunaan metafora.

\section{HASIL DAN PEMBAHASAN}


Berdasarkan hasil penelitian yang dilakukan oleh peneliti dapat dianalisis bahwa manajemen Diklat yang yang di diselenggarakan oleh Santri Siap Guna Daarut Tauhiid untuk membentuk karakter santri Baku telah menerapkan prinsip-prinsip manajemen Diklat. Hal ini, terbukti setelah peneliti mendatangi langsung ke beberapa pihak yang bersangkutan, termasuk peserta yang telah menyelesaikan Diklat Santri Siap Guna angkatan 32 dan respon yang mereka rasakan dapat dikatakan baik. Sehingga terbukti bahwa Diklat SSG ini mampu membentuk karakter Baku pada peserta.

Untuk menjalankan semua tentunya dibutuhkan manajemen yang sesuai dalam pelaksanaan diklat. Sebagaimana yang di teliti oleh peneliti mengenai manajemen diklat SSG yang meliputi 3 (tiga) aktivitas utama yaitu; perencanaan, pelaksanaan dan evaluasi. Berikut adalah aktivitas manajemen Diklat yang diselenggarakan oleh SSG DT.

\section{Perencanaan Diklat Santri Siap Guna Daarut Tauhiid Angkatan 32}

Perencanaan merupakan tahapan paling penting dalam suatu fungsi manajemen diklat, terutama dalam menghadapi lingkungan eksternal yang berubah dinamis. Perencanaan yang baik akan dapat membantu lembaga penyelenggara dalam melaksanakan kegiatannya dengan terpadu sehingga dapat mencapai hasil yang maksimal. Keefektifan dan keefisienan pelaksanaan diklat sangat dipengaruhi oleh bagaimana programnya di desain. Itu sebabnya dalam penyusunan program pelatihan perlu diperhatikan supaya program pelatihannya sesuai dengan kompetensi yang dibutuhkan peserta. Dengan kata lain perencanaan program pelatihan yang baik adalah perencanaan yang didasarkan pada beberapa proses diklat, yaitu: analisis kebutuhan pelatihan, tujuan diklat, peserta diklat, anggaran biaya, waktu atau jadwal pelaksaan diklat, materi atau kurikulum diklat, pemateri, peralatan, tempat diklat, dan kepantiaan.

Perencanaan Diklat SSG DT 32 telah memenuhi hal-hal yang harus diperhatikan pada tahap perencanaan sesuai yang dikemukakan oleh Davies yang mengatakan bahwa dalam merencanakan diklat harus memperhatikan tahaptahapnya, yaitu; latar belakang diklat (analisis kebutuhan) dilakukan dengan cara mengamati fenomena dan kejadian nyata yang ada disekitar. Fenomena yang dipotret adalah bahwa perilaku muslim belum menunjukkan jati diri muslim yang sesungguhnya. Banyak muslim yang jorok, tidak taat peraturan, dan lainnya.. Maka yang diharapkan dengan adanya pelatihan ini adalah semakin banyak yang dapat hidayah dari SSG semoga semakin banyak muslim yang punya karakter baku, menepis pandangan bahwa muslim lemah, kotor, tidak mengamalkan nilai keislaman nya. Target nya semakin banyak orang yang tau dan menerapkan nilai di SSG semoga muslim lebih baik lagi.

Tujuan diklat SSG antara lain: Terbentuknya pribadi berkarakter Baik dan kuat (Baku) yang produktif dalam berbuat kebaikan, Menjadikan peserta didik atau lebih dikenal sebagai santri yang memiliki jiwa "Pelopor, Mandiri dan Ahli Khidmat", Santri mampu menjadi agen perubahan di masyarakat, Santri memiliki jiwa korsa "Tiada Kesetiaan Tanpa kesetiaan", Mengajarkan siswa untuk bisa 
mandiri, Perekrutan seleksi peserta dilakukan pada tanggal 23 Mei 2016 s/d 28 Juli 2016 sebelum diadakan nya pelatihan. Perekrutan seleksi peserta terbagi menjadi 2 (dua) cara yaitu melalui online dengan cara mengisi formulir online data diri di alamat www.ssg-dt.org/daftar atau langsung datang ke kantor SSG, peralatan, biaya diklat SSG, peserta dikenakan biaya sebesar Rp.350.000 yang dipergunakan untuk fasilitas peserta.

Waktu dan tempat kegiatan Diklat SSG DT 32 dilakukan didalam lingkungan dan diluar lingkungan Daarut Tauhiid. Dilaksanakan dibeberapa lokasi sebagai berikut : Pondok Pesantren Daarut Tauhiid Bandung merupakan tempat yang strategis dengan sarana dan prasarana kegiatan (berupa Gedung Serba Guna Daarul Haaj, Daaru'llmi, lapangan central V, lapangan central VII, Muslimah Center, Aula Daarul Hidayah. Masjid DT) serta berlokasi dekat dengan Kampus Universitas Pendidikan Indonesia (UPI) dan Pusdiklas Kodiklat TNI-AD yang mempermudah terlaksananya program diklat yang menekankan keterampilan sosial, kesamaptaan Jasmani dan ruhiyah, Area Curug Sigey untuk kegiatan orientasi Medan (ormed). Rappeling di Curug dan kegiatan (Pertolongan Pertama Gawat Darurat (PPGD), Kawasan Eco Pesantren Daarut Tauhlid Bandung yang sangat menunjang kegiatan Diklat SSG DT 32 dalam latihan simulasi Gerak Reaksi, Simulasi Reptil, Memanah dan Berkuda, Kawasan Kampus UPI merupakan kawasan terpadu yang sangat menunjang kegiatan Diklat SSG DT Angkatan 32 : Gelora Olah Raga UPI untuk kegiatan lapangan Berdebu dan Lapangan Driving UPI untuk kegiatan Muhasabah setelah dilaksanakan Ormed. Perang Badar, Pusat Pendidikan Jasmani (Pusdikjas Kodiklat) TNI -AD, Area Pondok Hijau dengan topografi adalah dataran tinggi dan dataran rendah. Akses menuju Eco pesantren Daarut Tauhiid dan sekaligus daerah yang sangat baik untuk longmarch, melatih kekuatan fisik dan jiwa korsa peserta Diklat SSG-DT 32, Kawasan Kota Bandung dan sekitarnya menjadi lokasi kegiatan Diklat SSG DT 32 untuk aktivitas sebagai berikut:Longmarch. Lapangan Racin Cipedes (Kegiatan Perang Badar), Khidmat baksos yang dipusatkan di kawasan Kelurahan Cibeunying, Sadang Serang dan Sukasari, Praktek wirausaha (Kawasan Monumen Perjuangan Rakyat Jawa Barat dan Lapangan Gasibu, Car Free Day Dago Pemkot Cimahi), Curug Layung dan Kawasan Kegiatan Pertempuran Hutan Kopassus Cijanggel, kepanitiaan terdiri dari Korps pelatih SSG .

Perangkat Kegiatan diklat terdiri dari Term of Reference adalah kerangka acuan kegiatan yang memuat garis besar kegiatan dan jadwal berisi tentang rencana kegiatan dalam program yang akan dilaksanakan. Kurikulum diklat, ialah rencana materi yang akan disampaikan dalam suatu pelaksanaan diklat, yang telah ditetapkan, sesuai dengan tujuan yang ingin dicapai. Kurikulum diklat SSG DT dibentuk oleh tim dengan menyesuaikan keadaan dan kebutuhan saat Diklat, serta kurikulum bersifat dinamis yang terdiri dari proses Dobrak diri, Bangun diri dan Bangun tim.

Dalam mempublikasikan kegiatan diklat SSG DT 32. Tim yang sudah terbentuk mempromosikan kegiatan yang akan diselenggarakan ini dengan 
beberapa media. Adapun media publikasi kegiatan Diklat SSG DT 32 melalui beberapa yaitu, sebagai berikut: Pamflet, Brosur, Website http://ssgdt.daaruttauhid.org, Sosial Media (Twitter, Facebook, Instagram), Informasi di pengajan rutin dan ibadah di Daarut Tauhid seperti; Kajian MQ Pagi, Kajian Ma'rifatullah, Pengumuman Sebelum Shalat Jum'at, dll, Informasi dan iklan di radio MQ 102.7 FM. Sasaran kegiatan Diklat SSG-DT Angkatan 32 adalah generasi yang memenuhi persyaratan sebagai berikut: Usia 17-35 tahun, Beragama Islam, Berjenis kelamin lkhwan atau Akhwat, Melengkapi persyaratan administrasi pas foto 2x3 warna 2 lembar, Fotokopi KTP / KTM / SIM., Surat Keterangan Sehat dari dokter, Surat Rekomendasi dari organisasi (jika ada).

Anggaran biaya diklat, waktu pelaksanaan kegiatan diklat. peralatan diklat yang digunakan yaitu peralatan praktek, peralatan media berupa Overhead Projector, LCD projector, Whiteboard, dan lain sebagainya. Dalam pembentukan kepanitian termasuk didalamnya pelatih. Pengurus inti yang terdiri dari 5 (lima) orang, beranggotakan Pak Dadan, Pak Nurhadi, Bu Risya, kang Henry dan Teh Sulis mengadakan rapat internal, setelah itu memanggil para pelatih yang tergabung dala korps pelatih untuk pembentukan kepanitian. Sebelum membentuk panita, para panita dan pelatih adalah SSG yang dinyatakan telah lulus mengikuti SSG, sebelumnya harus melaksanakan proses Diklat Pembentukan Pelatih atau Dikutih.

Menyusun kurikulum diklat, ialah rencana materi yang akan disampaikan dalam suatu pelaksanaan diklat, yang telah ditetapkan, sesuai dengan tujuan yang ingin dicapai. Kurikulum diklat SSG DT dibentuk oleh tim dengan menyesuaikan keadaan dan kebutuhan saat Diklat, serta kurikulum bersifat dinamis. Setelah perumusan kurikulum yang dibentuk oleh panitia Diklat selesai dirumuskan. Tahap selanjutnya yaitu menghubungi pemateri yang sudah ditentukan pada kurikulum diklat. Menghubugi pemateri dilakukan minimal seminggu sebelum pelatihan. Adapun untuk pemateri ada dari orang dalam dan dari luar Daarut Tauhiid. Untuk pemateri dari luar, pemateri dipilih secara selektif oleh panitia dan pemnetapan pemateri pun harus menyesuaikan kembali dengan pimpinan yayasan yaitu KH. Abdullah Gymnastiar.

\section{Pelaksanaan Diklat Santri Siap Guna Daarut Tauhiid Angkatan 32}

Berdasarkan hasil penelitian bahwa selama pelaksanaan diklat berlangsung, kegiatan diklat mampu mengkolaborasikan antara unsur-unsur pelatihan. Semua ini demi tertujunya pencapaian tujuan dan sasaran diklat. Dalam kegiatan diklat ini peserta memperoleh materi pelajaran yang telah di programkan sesuai dengan kurikulum dan jadwal diklat. Pelaksanaan proses belajar mengajar ini baik di kelas maupun di luar kelas sesuai dengan metoda dan media yang telah di tetapkan.

Sukses tidaknya diklat akan sangat bergantung dengan pelaksanaan. Dalam diklat ini, panita berusaha semaksimal mungkin untuk menghasilkan yang terbaik dengan melaksanakan semua tahap dan proses yang ada dalam perencanaan. Perilaku yang diterapkan panitia dan pelatih menunjukkan sikap Baku dalam segala hal sehingga menciptakan keefektifan dalam penerapan pada diri peserta. 
Dalam pelaksanaan kegiatan diklat terkadang mengalami kendala pada tempat pelatihan, yang sering bentrok dengan kegiatan yang ada di Daarut Tauhiid. Sehingga menyebabkan bergantinya jadwal dari yang sudah direncanakan. Namun, kendala ini masih dapat diatasi oleh pihak panita dengan cara mengganti jadwal dengan menyesuaikan kondisi atau mencari tempar diluar DT untuk pelaksanaan kegiatan. Kendala lain yang dihadapi yaitu gugur nya beberapa peserta di masa Diklat dan tidak bertahan hingga akhlandasanir. Panitia dan pelatih berusaha untuk terus mengkonfirmasi dan mengingatkan kepada peserta yang merasa cukup dalam Diklat ini untuk kembali bergabung kembai dan mengikuti Diklat, namun keputusan tetap ada pada peserta.

Penutupan diklat dilaksanakan setelah semua rangkaian kegiatan dilalui. Penutupan dilakukan di Daarut Tauhiid dengan upacara penutupan. Upacara dilakukan secara khidmat yang dapat dinyatakan bahwa peserta lulus dala diklat SSG DT 32. Namun sangat disayangkan peserta yang tercatat diawal tidak sesuai dengan yang ada hingga akhir karena ada beberapa peserta yang mengundurkan diri di masa diklat. Pada tahap pelaksanaan Diklat Santri Siap Guna Daarut Tauhiid telah melaksanakan tahap pelaksanaaan dengan baik sesuai dengan teori Aep Kusnawan Kusnawan (2009:118), bahwa pada tahap pelaksanaan yang harus diperhatikan adalah pembukaan Diklat, Pelaksanaan pengajraran, dan di akhiri dengan penutupan. Pelaksanaan diklat SSG DT 32 mengacu pada agenda acara yang telah dibuat dan direncanakan diawal.

Berpedoman pada run down yang telah dirancang sebelumnya yang berisi beberapa informasi diantaranya alokasi waktu setiap sesi, rincian kegiatan, materimateri pelatihan, peralatan yang dibutuhkan, tugas-tugas setiap panitia, dan tahap-tahap pelaksanaan pelatihan yaitu diawali dengan pra-diklat, pembukaan diklat, pelaksanaan diklat dan penutupan.

Tahapan kegiatan pelaksanaan SSG DT 32, sebagai berikut: pertama, pradiklat SSG DT 32, bertujuan untuk memperkenalkan tata nilai dan budaya Daarut Tauhiid dan SSG. Agar peserta diklat mengenal dan mampu menerapkan serta melakukan penyesuaian terhadap budaya ini maka dikenalkan sejak awal pelatihan. Adapun budaya Daarut Tauhiid yang diperkenalkan adalah sebagai berikut: BRT'T (Bersih, Rapih, Tertib, Teratur), TSP (Tahan Buang Sampah Sembarangan, Simpan Sampah Pada Tempatny, Pungut Sampah Insyaallah Sedekah). BeBasKoMiBa (Bersih Rapihkan, Basah Keringkan, Kotor Bersihkan, Miring Luruskan, Bahaya Amankan).

Konsep tata nilai budaya Daarut Tauhid ini diharapkan selalu diimplementasikan dalam kehidupan sehari-hari santri. Dikelola secara bersamasama untuk mendapatkan lingkungan yang Bersih, Nyaman, Aman, dan Teratur. Konsep inilah yang mendasari kegiatan- kegiatan yang dilakukan SSG, agar senantiasa menjaga lingkungan dimanapun mereka berada.

Materi ini diberikan untuk memberikan gambaran dan mensosialisasikan budaya yang ada dalam yayasan Daarut Tauhid. Kemudian memperkenalkan tentang ke-SSG-an yang diawali dengan kontrak belajar, Pengantar Pelatihan, 
PUD. Bertujuan Memberikan gambaran peraturan dan tata tertib yang berlaku selama peserta mengikuti pelatihan. Pada pra-diklat ini juga peserta dibagikan kelompok latihan selama 3 (tiga) bulan kedepan berikut dengan pelatih pendampingnya.

Kedua, pembukaaan Dikat, dilaksanakn tanggal 6 Agustus 2016. Peserta berkumpul di Dome Central V untuk mengikuti gladi upacara pembukaan yang langsung dihadiri dan dibuka oleh pimpinan KH. Abdullah Gymnastiar. Pembukaan ini sekaligus memasuki tahapan pelatihan pekan pertama yang beragendakan pengenalan panitia. Pada pembukaan ini juga kegiatan pelatihan pertama dimulai. Ketiga, kegiatan belajar mengajar.

Pada langkah ini merupakan kegiatan pelaksanaan program pelatihan yang berpedoman pada kurikulum. Melalui metode yang akan menjadikan peserta atau santri mempunyai karakter Baku. Santri Siap Guna dalam pendidikan dan pelatihan nya bertuuan untuk menuju pribadi berkarakter. Tentunya dalam membentuk karakter tidaklah semudah seperti mengembalikkan telapak tangan. Karena karakter adalah sesuatu yang sudah mengakar, mulai dari pola pikir, pola sikap, pola tindak dan dianggap kebenaran sehingga untuk merubah pola karakter seseorang yang sesuai dengan karakter BAKU yaitu Baik dan Kuat.

Dalam pembagian besar itu, baik dan kuat nya, didalam SSG ini pelatihan menggunakan dengan 2 (dua) model kepelatihan. Yaitu dengan model kepelatihan pesantren dan model kepanduan. Pertama, Model Kepesantrenan, yaitu nilai-nilai yang SSG ajarkan, tentang kesilaman, keyakinan pada Allah, dan peningkatan niai ruhiyah. Serta aturan-aturan dan budaya yang ada di dalam lingkungan Daarut Tauhiid. Kedua, model Kepanduan, bertujuan untuk mendobrak diri, SSG tidak menggunakan istilah militer dengan jorje system, tapi dengan treatmen dan tekanan. Semua ini di arahkan bukan untuk gagah-gagahan.

Dalam SSG yang diambil adalah pengambilan hikmah dari setiap kejadian yang dihadapi. Dilatih dengan seperti halang rintang, ketinggian, mengalahkan perasaan takut dan diarahkan untuk tafakur diri dan berfikir betapa lemahnya kita sebagai manusia. Sehingga diharapkan 2 karakter inilah, baik dan kuat yang akan terbentuk sebagaimana yang diharapkan Islam dewasa ini. Karena jika kita lihat di sejarah lampau Islam zaman rasul dan sahabat. Hebat nya Islam jaya dan berkembang karna 2 (dua) karakter ini.

Daarut Tauhiid adalah wilayah dzikir, fikir, ikhtiar, betul-betul di terapkan seperti ada 5 pantangan Budaya Daarut Tauhiid): pantang sia-sia, pantang mengeluh, pantang menjadi beban, pantang berkhianat, pantang kotor hati. Sehingga dalam metode pembelajaran berdasarkan pada tujuan kegiatan diklat SSG memiliki 3 (tiga) tahapan Diklat yang harus dilalui, untuk membentuk karakter BAKU. Adapun tahap-tahap dalam pelaksanaan Diklat SSG, yaitu: pertama, dobrak diri. merupakan tahap pertama dalam Diklat SSG yang dimulai dengan tahap kegiatan masa orientasi dan tahapan awal Diklat bertujuan untuk mengosongkan mindset, paradigma, ego peserta untuk siap masuk di program/lingkungan pelatihan SSG. 
Dalam tahapan awal untuk mengosongkan mindset, paradigm, dan ego, peserta juga diberikan materi pengantar diklat oleh kepala SSG DT dengan tujuan agar mendapat pemahaman yang lebih tentang Diklat SSG. Selain itu, peserta diajak untuk mendobrak, mengalahkan atau mengatasi hambatan psikologi peserta yang dapat menghambat kemajuan, phobia, trauma ataupun malas dengan diberikan kegiatan-kegiatan fisik serta membiasakan diri untuk shalat berjamaah, melaksanakan shalat sunah dhuha dan tahajud. Materi yang disajikan dalam tahap awal atau dobrak diri yaitu: Fiqh praktis, Orientasi Medan, Muhasabah, Tahsin, Aqidah, Pengenalan Khidmat, Mentoring peserta dengan pelatih pendamping, Longmarch, PBB, Mindset Reframing, Rappelling, Halang Rintang.kedua, bangun diri. Setelah melewati tahapan dobrak diri, peserta diklat menjalankan tahapan bangun diri untuk mengisi diri dengan wawasan ilmu, pengalaman, tata nilai positif yang menjadi bekal bagi setiap individu untuk kemandiriannya, baik ilmu maupun sikap hidup keterampilan.

Materi Diklat pada tahap Bangun Diri: Tahsin, Ta'lim Muta alim, Longmarch, Simulasi Reptil, Manajemen Organisasi, Badar game, Karakter Baku, Motivasi Musim, Berkuda, Memanah, Birul Walidain, Dzikrul Maut (Cerdas Menghadapi Kematian). Ketiga, bangun tim. Setelah melewati tahapan bangun diri. Peserta diklat menjalankan tahapan bangun tim untuk melatih mengasah, membiasakan individu untuk dapat berinteraksi dengan pihak lain dalam membangun kerjsama dalam tim atau kelompok. Dirancang untuk terbangunnya kepekaan, empati, sikap bijak, saling membantu dalam kerjasama tim atau kelompok.

Materi Diklat tahap akhir atau Bangun Tim: (Motivasi Wirausaha, Public Speaking, Praktek Wirausaha, Bakti Sosial, Camp Management, Unlocking Potential Power, Penyebrangan Basah, Membangun tim efektif, Bivak Regu, Jurit Malam, Solo Bivak).

Selain diberikan materi sebagai langkah pembentukan karakter di wilayah Daarut Tauhiid. Para peserta juga diberikan buku Mutabaah Yaumiyah yang berisi tentang amalam positif selama pelatihan. Buku ini berfungsi untuk memonitoring aktivitas ibadah peserta. Buku ini dibawa kerumah dan dikumpulkan dengan buku tugas saat pekan selanjutnya.

Diharapkan setelah pelatihan pun peserta sudah terbiasa mengamalkan kebiasaan positif yang mulai terbangun saat masa diklat. Sebagai tolak ukur bahwa peserta mampu menjadi pribadi berkarakter Baku.

Penutupan Diklat SSG 32 dilaksanakan di Dome Central Daaruut Tauhiid. Penutupan dilaksanakan melalui upacara dan pengukuhaan peserta yang ditutup oleh Aa Gym. Pada penutupan ini jumlah peserta berkurang dari awal diklat. Peserta ada yang mengundurkan diri di masa diklat karena beberapa faktro diantaranya: tidak sanggup melewati tahapan diklat, kaget dengan diklat yang diselenggarakan dan sebagainya.

\section{Evaluasi Diklat Santri Siap Guna Daarut Tauhiid Angkatan 32}


Evaluasi pelatihan merupakan kegiatan penilaian yang dilakukan kepada peserta dan panitia untuk menilai proses pelaksanaan pelatihan. Suatu kegiatan yang bertujuan mengukur keberhasilan diklat dalam pengertian dengan cara mengukur perbedaan antara keadaan peserta sebelum masuk diklat dengan keadaan peserta sesudah menyelesaikan diklat. Adakah perkembangan, kemajuan atau peningkatan kinerja atau sebaliknya, menurun atau tetap tidak mengalami perubahan. Evaluasi juga merupakan kegiatan untuk memilih kegiatan pendidikan selanjutnya, apakah program diklat perlu ditingkatkan. Proses evaluasi masuk dalam kegiatan pelaksanaan pelatihan yang dilakukan pada akhir sesi.

Berdasarkan hasil observasi proses pelaksanaan pelatihan menunjukkan bahwa proses evaluasi dilakukan untuk menilai proses pelatihan baik kepada panitia maupun peserta, peserta dengan mengisi kuesioner yang didalamnya berisi kriteria-kriteria evaluasi pelatihan oleh peserta.

Evaluasi kegiatan diklat SSG. Pihak penyelenggara melakukan 2 (dua) evaluasi bertingkat. Pertama, evaluasi kepantiaan inti dilakukan pasca diklat. Membicarakan apa yang terjadi, apa yang sesuai, apa yang tidak sesuai, apa yang harus diperbaiki. Memantapkan perencanaan berikutnya, dipertajam di breafing kamis. Untuk evaluasi panitia dan pelatih, evaluasi panitia dipimpin oleh pimpinan atau kasubag diklat yang di evaluasi dari masing-masing pekerjaan atau jobdesknya. Contoh, Evaluasi perdivisi: Administrasi keuangan: evaluasi mengenai kehadiran, absen peserta, Tim medis: mengenai kesehatan serta kelengkapan obat peserta, Pelatih Pendamping: perkembangan karakter baik peserta, Komdis: perkembangan karakter kuat peserta.

Evaluasi peserta yang dilakukan SSG terhadap peserta dilakukan setiap selesai kegiatan, evaluasi peserta: SSG menerapkan manajemen ISO, yaitu survey kepuasan pada peserta. Kegiatan evaluasi penyelenggaraan pertahapan diklat dilakukan 1 (satu) sebulan sekali. Kedua, evaluasi manajemen, dilakukan hari senin (breafing manajemen). Ada evaluasi yang cukup dibahas di level kepanitiaan (pelaksana). Level evaluasi pengambilan keputusan, disikapi oleh manajemen, karena berhungungan langsung dengan atasan maka dilakukan evaluasi dihari senin.

Berdasarkan hasil penelitian evaluasi yang dilakukan dalam penyelenggaraan Diklat SSG, evaluasi dilaksanakan sesuai dengan kebutuhan dan dilaksanakan secara berjenjang dengan menggunakan media baik secara formal maupun non formal, lisan maupun tulisan seperti laporan keterlaksanaan atau proses kegiatan diklat dari pelatih pendamping setiap kelompok kepada komandan diklat, observasi langsung ke lapangan oleh komandan diklat yang kemudian dilaporkan kepada kabag diklat dan diteruskan kepada kepala SSG DT, ataupun pengamatan lansung ke lapangan oleh kabag diklat dan kepala SSG DT.

Adapun tahap evaluasi yang dilakukan setelah diklat SSG DT terdiri dari 2 (dua) sasaran evaluasi.

Evaluasi yang pertama dilakukan kepada peserta dan pelatih yang kedua dilakukan kepada tim manajemen. Evaluasi SSG DT 32 bertujuan untuk 
membicarakan apa yang terjadi,apakah ada ketidaksesuaian dan apa yang harus diperbaiki. Hal ini sesuai dengan teori Davis yang mengatakan bahwa evaluasi pelatihan dan tindak lanjut sangat penting untuk mengetahui berbagai kekurangan, kelemahan, dan kelebihan, baik penyelenggaraan pelatihan maupun proses yang terjadi.

Dalam evaluasi kepada peserta. Penyelenggara Diklat SSG melakukan survey kepuasaan peserta berbentuk kuesioner yang diisi pada saat latihan terakhir. Hal ini sesuai dengan teori Patrick yang menyatakan bahwa evaluasi tingkat reaksi diukur melalui tingkat kepuasan peserta terhadap proses dan hasil pelatihan yang diperolehnya.

Kondisi ini telah sesuai dengan evaluasi yang digunakan di lembaga SSG DT 32 antara lain: materi pelatihan sesuai dengan kebutuhan; sikap profesionalisme pemateri terhadap peserta; kerapihan penyajian pelatihan; metode penyajian pemateri; gaya, sikap, perilaku dan bahasa yang mudah dipahami; pemberian motivasi kepada peserta; pelayanan tim terhadap peserta; mampu membuat lebih percaya diri; dan mampu menggali potensi peserta. Sedangkan untuk evaluasi panitia serta kegiatan dilaksanakan setelah diklat selesai dilakukan per pekannya. Kegiatan evaluasi SSG DT 32 sudah melaksanakan terhadap seluruh komponen diklat seacara terpadu sejak dari perencanaan, persiapan, pelaksanaan hingga hasil dan dampak diklat serta rencana tindak lanjut

\section{PENUTUP}

Berdasarkan hasil penelitian dan pembahasan terhadap manajemen pendidikan dan pelatihan Santri Siap Guna dalam membentuk karakter santri Baku yang telah dilakukan. Yaitu, yang difokuskan pada perencanaan, pelaksanaan dan evaluasi. Maka hasil penelitian ini dapat disimpulkan bahwa, Perencanaan diklat yang dilakukan Santri Siap Guna Daarut Tauhiid angkatan 32 berdasarkan unsur-unsur perencanaan diklat, dengan memperhatikan hal-hal yang perlu ada saat perencanaan. Proses perencanaan diklat SSG DT yaitu: analisis kebutuhan pelatihan dengan tahapan pengamatan, tujuan diklat, peserta diklat adalah peserta umum dengan persyaratan yang telah ditetapkan, anggaran biaya diperuntukan untuk fasilitas dan saranana prasarana peserta, waktu dan jadwal pelaksanaan diklat. Jadwal pelaksanaan dilaksanakan akhir pekan agar menyesuaikan dengan waktu potensi peserta, tempat diklat dilaksanakan didalam dan di luar lingkungan Daarut Tauhiid, peralatan media yang digunakan LCD dan Projector, Whiteboard dan kepanitiaan terdiri dari lulusan yang sudah dinyatakan lulus SSG dan telah mengikuti proses Diktutih.

Pelaksanaan diklat Santri Siap Guna Daarut Tauhiid angkatan 32 diawali dengan pra-diklat untuk penanaman pemahaman budaya Daarut Tauhiid dan penyesuaian ke-SSG-an, kemudian pekan selanjutnya yaitu Pembukaan diklat yang diawali dengan doa pembuka bersama dilanjutkan serta upacara ceremonial dan sambutan oleh pimpinan dari pihak panitia sekaligus membuka pelatihan. Kemudian mulai kegiatan diklat pekan pertama selama 2 hari 1 malam. Sesi materi 
diberikan kepada peserta, dimana materi saling bersinergi dengan tema, metode, pemateri, penggunaan tempat, dan dikelola oleh panitia diklat. Setelah pekan pertama berakir maka diadakan penutupan yang berisi informasi untuk pekan selanjutnya serta pemberian tugas kepada peserta. Evaluasi diklat diklat Santri Siap Guna Daarut Tauhiid angkatan 32 sebagai tahap akhir dari manajemen diklat yang dilakukan oleh penyelenggara. Evaluasi dilakukan pada panitia serta peserta dan tim manajemen. Waktu untuk evaluasi diadakan selepas kegiatan berakhir. Evaluasi pertama diberikan kepada panitia beserta pelatih mengenai kegiatan yang telah dilaksanakan,bertujuan untuk melakukan perbaikan pada diklat pekan berikutnya. Evaluasi dimulai dari masing-masing bidang yang mananggungjawabi pekerjaan atau job desk masing-masing.

Evaluasi peserta menggunakan alat evaluasi yaitu kuesioner yang dibagikan kepada peserta setelah akhir latihan selama 3 (tiga) bulan. Untuk melihat kepuasan peserta dalam penyelenggaraan diklat. Kondisi ini telah sesuai dengan evaluasi yang digunakan di lembaga SG DT 32 antara lain: materi pelatihan sesuai dengan kebutuhan; sikap profesionalisme pemateri terhadap peserta; kerapihan penyajian pelatihan; metode penyajian pemateri; gaya, sikap, perilaku dan bahasa yang mudah dipahami; pemberian motivasi kepada peserta; pelayanan tim terhadap peserta; mampu membuat lebih percaya diri; dan mampu menggali potensi peserta. Serta ada penindaklanjutan kepada peserta setelah program diklat selesai. Evaluasi tim manajemen dilakukan hanya kepada pengurus inti untuk membicarakan hal-hal yang terkait dengan pusat.

Berdasarkan hasil penelitian dan pembahasan terhadap manajemen pendidikan dan pelatihan Santri Siap Guna dalam membentuk karakter santri Baku yang telah dilakukan. Yaitu, yang difokuskan pada perencanaan, pelaksanaan dan evaluasi. Maka hasil penelitian ini dapat disimpulkan bahwa, Perencanaan diklat yang dilakukan Santri Siap Guna Daarut Tauhiid angkatan 32 berdasarkan unsur-unsur perencanaan diklat, dengan memperhatikan hal-hal yang perlu ada saat perencanaan. Proses perencanaan diklat SSG DT yaitu: analisis kebutuhan pelatihan dengan tahapan pengamatan, tujuan diklat, peserta diklat adalah peserta umum dengan persyaratan yang telah ditetapkan, anggaran biaya diperuntukan untuk fasilitas dan saranana prasarana peserta, waktu dan jadwal pelaksanaan diklat. Jadwal pelaksanaan dilaksanakan akhir pekan agar menyesuaikan dengan waktu potensi peserta, tempat diklat dilaksanakan didalam dan di luar lingkungan Daarut Tauhiid, peralatan media yang digunakan LCD dan Projector, Whiteboard dan kepanitiaan terdiri dari lulusan yang sudah dinyatakan lulus SSG dan telah mengikuti proses Diktutih.

Pelaksanaan diklat Santri Siap Guna Daarut Tauhiid angkatan 32 diawali dengan pra-diklat untuk penanaman pemahaman budaya Daarut Tauhiid dan penyesuaian ke-SSG-an, kemudian pekan selanjutnya yaitu Pembukaan diklat yang diawali dengan doa pembuka bersama dilanjutkan serta upacara ceremonial dan sambutan oleh pimpinan dari pihak panitia sekaligus membuka pelatihan. Kemudian mulai kegiatan diklat pekan pertama selama 2 hari 1 malam. Sesi materi 
diberikan kepada peserta, dimana materi saling bersinergi dengan tema, metode, pemateri, penggunaan tempat, dan dikelola oleh panitia diklat. Setelah pekan pertama berakir maka diadakan penutupan yang berisi informasi untuk pekan selanjutnya serta pemberian tugas kepada peserta. Evaluasi diklat diklat Santri Siap Guna Daarut Tauhiid angkatan 32 sebagai tahap akhir dari manajemen diklat yang dilakukan oleh penyelenggara.

Evaluasi dilakukan pada panitia serta peserta dan tim manajemen. Waktu untuk evaluasi diadakan selepas kegiatan berakhir. Evaluasi pertama diberikan kepada panitia beserta pelatih mengenai kegiatan yang telah dilaksanakan,bertujuan untuk melakukan perbaikan pada diklat pekan berikutnya. Evaluasi dimulai dari masing-masing bidang yang mananggungjawabi pekerjaan atau job desk masing-masing. Evaluasi peserta menggunakan alat evaluasi yaitu kuesioner yang dibagikan kepada peserta setelah akhir latihan selama 3 (tiga) bulan.

Untuk melihat kepuasan peserta dalam penyelenggaraan diklat. Kondisi ini telah sesuai dengan evaluasi yang digunakan di lembaga SG DT 32 antara lain: materi pelatihan sesuai dengan kebutuhan; sikap profesionalisme pemateri terhadap peserta; kerapihan penyajian pelatihan; metode penyajian pemateri; gaya, sikap, perilaku dan bahasa yang mudah dipahami; pemberian motivasi kepada peserta; pelayanan tim terhadap peserta; mampu membuat lebih percaya diri; dan mampu menggali potensi peserta. Serta ada penindaklanjutan kepada peserta setelah program diklat selesai. Evaluasi tim manajemen dilakukan hanya kepada pengurus inti untuk membicarakan hal-hal yang terkait dengan pusat.

\section{DAFTAR PUSTAKA}

Daryanto. (2014). Manajemen Diklat, Yogyakarta: Media Gava.

Gintings, Abdorrakhman. (2011). Esensi Praktis Manajemen Pendidikan dan Pelatiban, Bandung: Humaniora.

Hasibuan, Malayu SP. (2002). Manajemen Sumber Daya Manusia, Jakarta: Bumi Aksara.

Hasibuan, Malayu SP. (2011). Manajemen: Dasar, Pengertian dan Masalah, Jakarta: Bumi Aksara.

Kusnawan, Aep. (2009). Manajemen Pelatihan Dakwah, Jakarta: PT Rineka Cipta.

Muwafik Saleh, Akh. 2012 Membangun Karakrer dengan Hati Nurani :Pendidikan Karakater untuk Generasi Bangsa, Jakarta: Erlangga.

Sudewo, Erie. 2011. Best Practice Character Builiding: Menuju Indonesia Lebih Baik, Jakarta: Republika.

Tim Penyusun. (1990). Kamus Besar Bahasa Indonesia edisi ketiga, Jakarta: Balai Pustaka. 